melphalan with some decrease in $\gamma$-globulins but no influence on the depression. Four patients had macroglobulinaemia. One was treated for only a short time for external reasons. Another had a good response as regards macroglobulins. He lived in an old people's home, where he fell and broke his hip, finally dying from old age after melphalan had been discontinued for a long time. Two patients had excellent responses both clinically and biochemically on continuous treatment. Nine patients with myeloma had low $\gamma$-globulin values. Most of them had marked excretion of Bence Jones protein. Five died during the treatment but two had only short courses. Four are alive, three in rather good condition. In two other patients there was not very much influence on the $\gamma$-globulin values, which were not much increased before treatment. Clinically these patients responded well to treatment and are alive and active after 10 months on melphalan. Nine patients had excellent initial response with later relapse so far as $\gamma$-globulin is concerned. Only one of these patients has been taking the drug continuously. His general condition is excellent but his $\gamma$-globulins have returned to the same level as before treatment. All the others have had clinical relapses. Five have died from their disease after the stopping of treatment because of haematological or other complications. Of 34 patients on continuous treatment, 31 showed continued good results, both clinically and biochemically. Two have died from intercurrent cardiac disease. One died from reticulum-cell sarcoma and myeloma in spite of very low $\gamma$-globulin values. The others are in clinical and biochemical remission. In seven patients the treatment has been started recently and the influence on the $\gamma$ globulin values cannot therefore be judged. Seven patients have had only short courses because of complications. Only two are alive.

Twenty-two treated patients have died; in six the treatment was too short. Among these there was one patient with liver cirrhosis and cancer of the colon. Two severely anaemic persons were treated for hypercalcaemia. Three died from cardiac disease. Eight died from myeloma in spite of a full course (five or six had good initial results). One patient had amyloid. One had a fatal relapse after stopping treatment during a voyage to the U.S.A. One developed agranulocytosis ; she also had a pancreatic carcinoma.

In conclusion, it may be said that we have not seen any patient with marked increase in $M$ components where we have been able to give a full course of the drug who did not respond clinically and biochemically to the treatment. Severe anaemia, leucopenia, and thrombocytopenia are contraindications against starting treatment. In two such patients with hypercalcaemia this symptom was corrected but the ultimate result was fatal. It seems probable that patients with marked excretion of Bence Jones protein have a poorer prognosis than others. Our results indicate that stopping of treatment may result in severe relapse. Continuous treatment with $2 \mathrm{mg}$. every day or every other day should be given indefinitely if no haematological complications arise.

Pains usually disappear rapidly. Serum albumin increases with few exceptions. Anaemia may improve but was never healed; increasing anaemia has also been seen.

The drug seems to be very potent if given in sufficient doses. It is much superior to urethane. Comparisons with cyclophosphamide have not been made.

I wish to thank Professor A. Haddow and Dr. D. A. G. Galton for much help with obtaining the drug and many valuable discussions.

\section{REFERENCES}

Alwall, N. (1947). Lancet, 2, 388.

- (1952). Acta med. scand., 144, 114

Bergel, F., and Stock, J. A (1954). F. chem. Soc., P. 2409.

Bergsagel, D. E. (1962). Cancer Chemother. Rep., 16, 261

Bernard, J., Seligmann, M., and Danon, F. (1962). Nouv. Rev. franç. Hémat., 2, 611 .

Blokhin, N., Larionov, L., Perevodchikova, N., Chebotareva, L., and Merkulova, N. (1958).' Ann. N.Y. Acad. Sci., 68, 1128.

Heremans, J. F., Laurell, A. H., Martensson, L., Heremans, M. T., Laurell, C. B., Sioquist, J., and Waldenström, J. (1961). Acta med. scand., 170, Suppl. No. 367 .

Larionov, L. F.' (1959). Acta Un. int. Cancr., 15, 42.

Luttgens, W. F., and Bayrd, E. D. (1951). भ. Amer. med. Ass., 147, 824 Rundles, R. W., Dillon, M. L., and Dillon, E. S. (1950). F. clin. Invest., 29, 1243 .

Saltzman, F., and Borgström, H. (1950). Acta med. scand., 136, 388.

Swan, A. (1962). Proceedings of Eighth Congress of European Society of Haematology, Vienna, 1961, Part I, p. 162. Karger, Basle and New Hork.

Vaughn, J., and Raphael, S. S. (1956). Brit. med. 7., 1, 27.

Waldenström, J. (1944). Acta med. scand., 117, 216.

(1952). Advanc. intern. Med., 5, 398.

(1962b). In Harvey Lectures, No. 56, p. 211. Academic Press, London.

(1962a). In Progress in Hematology, edited by M. Tocantins, 3rd ed., p. 266. Grune and Stratton, New York.

\title{
Leucine-induced Hypoglycaemia and Oral Hypoglycaemic Drugs
}

\author{
R. J. JARRETT,* M.D. ; W. J. H. BUTTERFIELD, $†$ O.B.E., M.D., F.R.C.P.
}

The amino-acid L-leucine produces hypoglycaemia in some infants (Cochrane et al., 1956) and in some patients with pancreatic $\beta$-cell tumours (Schwartz et al., 1959). This hypoglycaemia is associated with increased levels of circulating insulin or insulin-like activity (Yalow and Berson, 1960 ; Butterfield et al., 1960 ; Weisenfeld and Goldner, 1961), but, apart from this, little is known of the mechanism(s) underlying leucine-induced hypoglycaemia. Fajans et al. $(1960,1963)$ have demonstrated that normal individuals treated with chlorpropamide become sensitive to the hypoglycaemic effect of

\footnotetext{
* Lecturer, Department of Experimental Medicine, Guy's Hospital, London.

† Professor of Medicine, Guy's Hospital Medical School, London.
}

leucine and that the hypoglycaemia is again associated with increased levels of circulating insulin, as measured by an immuno-assay method. This new information lod us to investigate the effects of two other oral hypoglycaemic agentstolbutamide, another sulphonylurea derivative, and the biguanide, phenformin. Cochrane (1960) suggested that leucine might normally play some part in the release of insulin, and that susceptible infants were simply hypersensitive. There is some evidence (Butterfield et al., 1962) that tolbutamide affects the uptake of certain amino-acids, including leucine, by human forearm muscle. It is possible, therefore, that the sensitizing effect of the sulphonylureas is due to enhanced uptake of leucine by the islets, and an attempt has been made to study this in the rat. 


\section{Methods}

Leucine-tolerance Tests.-After an overnight fast, four individuals received $150 \mathrm{mg}$. of $\mathrm{L}$-leucine per $\mathrm{kg}$. orally. Two specimens of capillary blood were obtained prior to the administration of the leucine and subsequently at 10 -minute intervals for 60 minutes. Three of these individuals had a similar test after five days' treatment with $0.5 \mathrm{~g}$. of tolbutamide three times a day, the last dose being taken on the evening before the test. Another eight individuals received tolbutamide $(2 \mathrm{~g}$. in four and $1 \mathrm{~g}$. in the others) orally after an overnight fast. Capillary blood sugars were estimated at 30-minute intervals for two-anda-half hours. Then L-leucine $150 \mathrm{mg}$. $/ \mathrm{kg}$. was taken orally and capillary blood sugars were subsequently estimated at $15-$ minute intervals for 75 minutes. In another four individuals leucine-tolerance tests were similarly performed one hour after the ingestion of phenformin, following an overnight fast. The doses were $100 \mathrm{mg}$. in two and $50 \mathrm{mg}$. in two. Blood sugars were estimated in the "autoanalyzer" (Technicon) by a ferricyanide reduction method (Hoffman, 1937).

Effect of Tolbutamide upon Leucine Metabolism by the Rat Diaphragm.-L-Leucine labelled with ${ }^{14} \mathrm{C}$ was obtained from the Radiochemical Centre, Amersham. The diaphragms were taken from male albino Wistar rats, weighing 100-150 g., starved for 24 hours and killed by decapitation. The two halves of the diaphragm were washed in freshly gassed Krebs-Ringer bicarbonate buffer, then gently blotted, weighed, and transferred to $25-\mathrm{ml}$. Erlenmayer flasks containing $2 \mathrm{ml}$. of medium. Each hemidiaphragm served as a control for the other half. The medium consisted of Krebs-Ringer bicarbonate buffer, with glucose to a final concentration of $200 \mathrm{mg}$. $/ 100 \mathrm{ml}$., and ${ }^{14} \mathrm{C}$ leucine $0.4 \mu \mathrm{c} / \mathrm{ml}$. Tolbutamide was added to some flasks to give final concentrations of $10^{-2}, 10^{-3}$, and $10^{-4}$, respectively. The flasks were gassed with a mixture of $95 \% \mathrm{O}_{2}$ and $5 \% \mathrm{CO}_{2}$ and incubated on a Dubnoff metabolic shaker at $37^{\circ} \mathrm{C}$. for 90 minutes. At the end of this time $1 \mathrm{ml}$. of "hyamine" was injected into the centre well, then the reaction stopped and $\mathrm{CO}_{2}$ was evolved by injecting $0.1 \mathrm{ml}$. of $10 \mathrm{~N} \mathrm{H}_{2} \mathrm{SO}_{4}$ into the medium. The flasks were then shaken for one hour at room temperature to trap the $\mathrm{CO}_{2}$ in the hyamine. At the end of this period the hyamine was removed from the centre well, added to $10 \mathrm{ml}$. of $0.3 \%$ diphenyloxazole in xylene (P.P.O.), and counted in a liquid scintillation counter. The results are expressed in counts per minute per gramme of tissue.

Incorporation of ${ }^{14} \mathrm{C}$-Leucine into Diaphragm Protein.Protein was prepared from the diaphragms by the method of Manchester and Young (1958). The weighed protein was taken up in $1 \mathrm{ml}$. of scintillator gel, added to $7 \mathrm{ml}$. of P.P.O. and counted in a liquid scintillation counter. The results are expressed as counts per minute per gramme of protein.

Chromatography.-At the end of the incubation 5- $\mu$ l. samples of the incubation medium were pipetted on to Whatman No. 4 filter-paper. When the spot was dry, $5 \mu \mathrm{l}$. of unlabelled Lleucine $(2.5 \mu \mathrm{mol} / \mathrm{ml}$.) was applied to the same place to act as a carrier. Leucine was separated by chromatography, the solvent consisting of $\mathrm{N}$-butanol (120 parts), glacial acetic acid (30), and distilled water (50). The system was run overnight, the spots were stained with ninhydrin $(0.2 \%$ in acetone) and then cut out, added to $5 \mathrm{ml}$. of P.P.O., and counted in a liquid scintillation counter.

Autoradiographic Studies.-Nine male Wistar rats, nonfasted and weighing 130-140 g., were used. Three rats were injected intravenously with $25 \mu \mathrm{c}$ of ${ }^{14} \mathrm{C}$-leucine and killed by decapitation at 30 seconds, 10 minutes, and 90 minutes respectively. The pancreas was removed immediately, immersed in $10 \%$ formol-saline, and later sectioned at $5 \mu$. Another three rats were treated exactly the same, but the leucine was preceded by $100 \mathrm{mg}$. of sodium tolbutamide per kg. intravenously. For comparison, the remaining three rats received 0.1 unit of glucagen-free insulin per $\mathrm{kg}$. intravenously, immediately before the injection of the labelled leucine. The leucine used was of the same specific activity throughout. After removal of the paraffin wax the mounted sections of pancreas were coated with Ilford K5 nuclear emulsion. Excess emulsion was removed and the slides were suspended in the dark-room until the emulsion had hardened. They were then stored vertically, face to back, with a space of about $2 \mathrm{~mm}$. between them, in an airtight lightexcluding box in a refrigerator at $5^{\circ} \mathrm{C}$. After storage the slides were developed for four minutes with constant agitation in $\mathrm{KD}$ $19 \mathrm{~B}$ developer ; rinsed in distilled water and fixed in acid fixer for 10 minutes; then washed in running water for one hour, dehydrated in alcohol, and dried. Finally, the sections were stained with haematoxylin and eosin. After inspection under both low and high power of the microscope, grain counts were made using the $1 / 6$ objective and a micrometer eyepiece. Counts were made of the central portion of four separate islets in each section after 14- and 21-day exposures. The islets chosen were at the margins of the section and background counts were made in the emulsion immediately adjacent.

\section{Leucine-tolerance Tests}

\section{Results}

The mean results of the fasting leucine-tolerance tests on four normal individuals are shown in Fig. 1. As has been

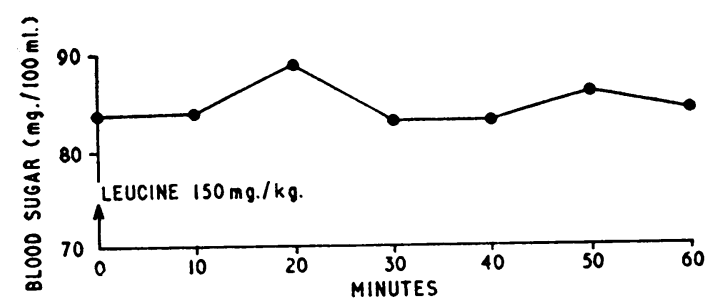

Fig. 1.-Fasting leucine-tolerance test (mean of tests on four normal individuals).

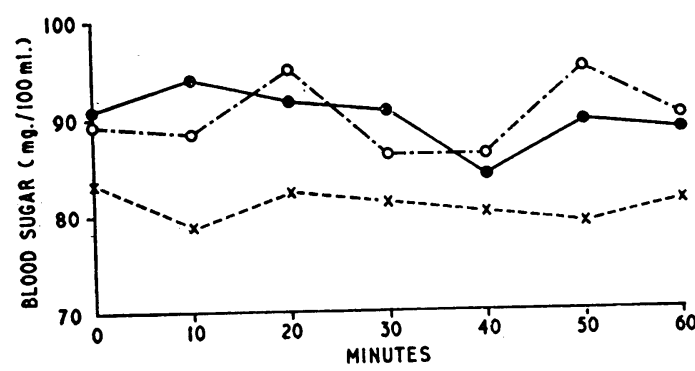

FIG. 2.-Leucine-tolerance test on three persons before tolbutamide administration.

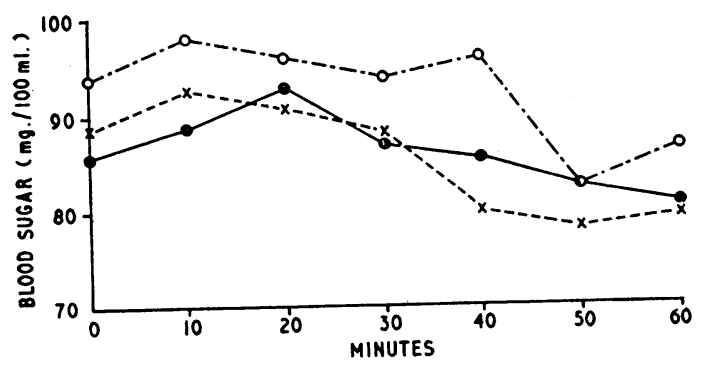

FIG. 3.-Leucine-tolerance test on same three persons as Fig. 2 after five days on tolbutamide.

repeatedly shown, leucine has no obvious effect on the normal human. Figs. 2 and 3 show the results of the tolerance test on three individuals, before and after five days of tolbutamide administration. In the second test the blood sugars have fallen slightly in all three individuals at 50 and 60 minutes and the mean fall is just significant at the $5 \%$ level. For the difference between the fasting and the 50-minute levels, $\mathrm{P}<0.05$, and at 
60 minutes $0.10>\mathrm{P}>0.05$. Figs. 4 and 5 show the results of the leucine-tolerance tests two-and-a-half hours after taking $2 \mathrm{~g}$. or $1 \mathrm{~g}$. of tolbutamide. In each individual the blood sugar fell after taking the tolbutamide, began to rise one-and-a-half to

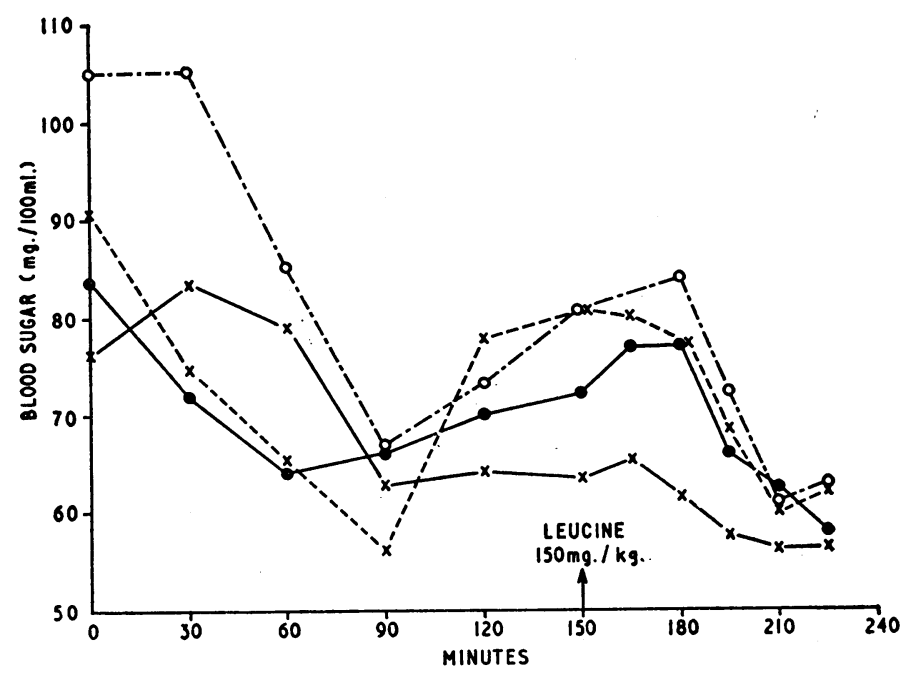

FIG. 4.-Leucine-tolerance test after $1 \mathrm{~g}$. tolbutamide orally.

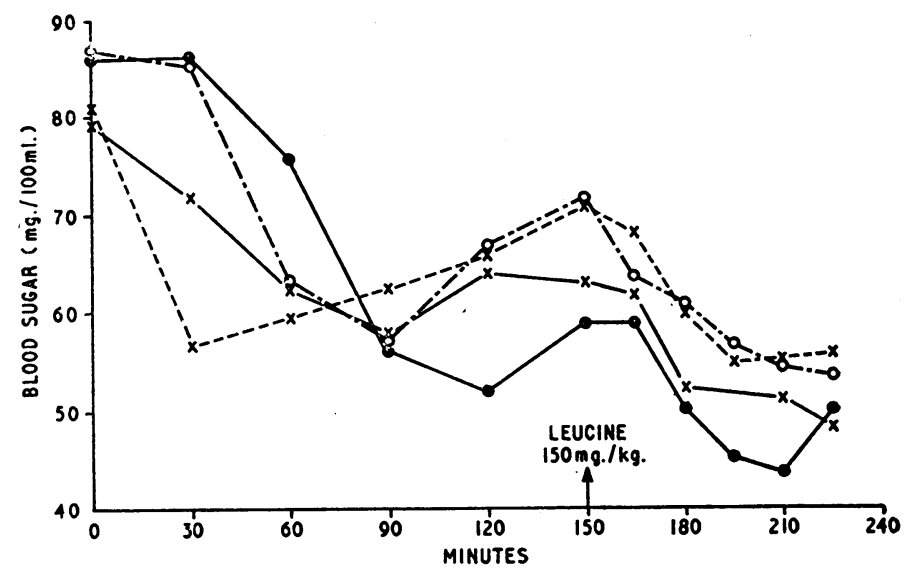

Fig. 5.-Leucine-tolerance test on same persons as in Fig. 4 after 2 g. tolbutamide orally.

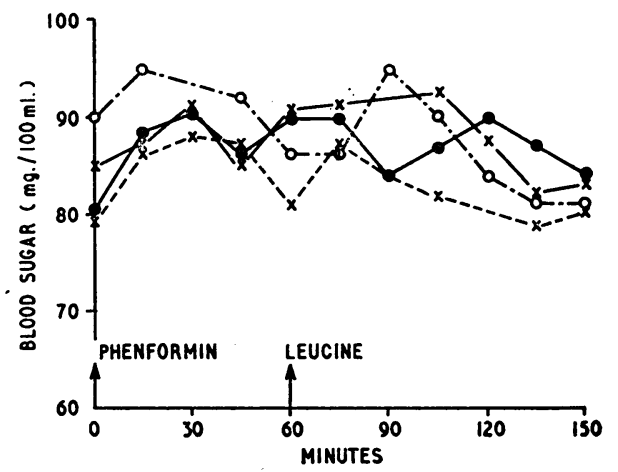

FrG. 6.-Leucine-tolerance test on four individuals after phenformin.

two hours later, and then fell again after the ingestion of the leucine. Thus tolbutamide, like chlorpropamide, can render normal individuals sensitive to the hypoglycaemic effect of leucine, and it may be inferred that this is a property of the sulphonylureas in general.

The results with phenformin (Fig. 6), however, were negative in four individuals, one of whom had previously shown a positive effect after tolbutamide.

\section{Leucine Metabolism by the Rat Diaphragm}

Table I shows the effects of different concentrations of tolbutamide upon ${ }^{14} \mathrm{CO}_{2}$ production from ${ }^{14} \mathrm{C}$-labelled leucine by the diaphragm. In concentrations of $10^{-3}$ and $10^{-4}, \mathrm{CO}_{2}$ production was not affected, but at a concentration of $10^{-2}$ it was significantly less. Table II shows the effect of different concentrations of tolbutamide on the incorporation of ${ }^{14} \mathrm{C}$ leucine into diaphragm protein. Again there was no effect with the two lower concentrations, but at a concentration of $10^{-2}$ tolbutamide reduced the amount of leucine incorporation. The results of the analysis of the incubation medium are shown in Table III. At the two lower concentrations of tolbutamide the amount of leucine remaining in the medium was the same as the control. However, in the high concentration $\left(10^{-2}\right)$ there

TABLB I.-Effect of Tolbutamide upon ${ }^{14} \mathrm{CO}_{2}$ Production from ${ }^{14} \mathrm{C}$ -

\begin{tabular}{|c|c|c|}
\hline $\begin{array}{l}\text { No. of } \\
\text { Experiments }\end{array}$ & $\begin{array}{l}\text { Incubation } \\
\text { Medium }\end{array}$ & $\begin{array}{l}\text { Mean Counts/ } \\
\text { min./g. Tissue }\end{array}$ \\
\hline 3 & $\begin{array}{l}\text { Tolbutamide } 10^{-2} \\
\text { Control }\end{array}$ & $\left.\begin{array}{l}178,880 \\
575,294\end{array}\right\} P<0.05$ \\
\hline 3 & $\begin{array}{l}\text { Tolbutamide } 10^{-3} \\
\text { Control }\end{array}$ & $\begin{array}{l}489,354 \\
496,702\end{array}$ \\
\hline 5 & $\begin{array}{l}\text { Tolbutamide } 10^{-2} \\
\text { Control }\end{array}$ & $\left.\begin{array}{l}233,900 \\
589,600\end{array}\right\} P<0.001$ \\
\hline 5 & $\begin{array}{l}\text { Tolbutamide } 10^{-3} \\
\text { Control }\end{array}$ & $\begin{array}{l}197,259 \\
177,587\end{array}$ \\
\hline 6 & $\begin{array}{l}\text { Tolbutamide } 10^{-4} \\
\text { Control }\end{array}$ & $\begin{array}{l}137,434 \\
158,908\end{array}$ \\
\hline
\end{tabular}

TABLE II.-Effect of Tolbutamide on Incorporation of ${ }^{14} \mathrm{C}$-labelled Leucine into Rat-diaphragm Protein

\begin{tabular}{|c|c|c|}
\hline $\begin{array}{c}\text { No. of } \\
\text { Experiments }\end{array}$ & $\begin{array}{l}\text { Incubation } \\
\text { Fluid }\end{array}$ & $\begin{array}{l}\text { Mean Counts/ } \\
\text { min./mg. Protein }\end{array}$ \\
\hline 4 & $\begin{array}{l}\text { Tolbutamide } 10^{-2} \\
\text { Control }\end{array}$ & $\left.\begin{array}{l}12,473 \\
57,414\end{array}\right\} P<0.01$ \\
\hline 6 & $\begin{array}{l}\text { Tolbutamide } 10^{-3} \\
\text { Control }\end{array}$ & $\begin{array}{l}98,183 \\
92,305\end{array}$ \\
\hline 4 & $\begin{array}{l}\text { Tolbutamide } 10^{-8} \\
\text { Control }\end{array}$ & $\begin{array}{l}31,397 \\
29,464\end{array}$ \\
\hline 6 & $\begin{array}{l}\text { Tolbutamide } 10^{-4} \\
\text { Control }\end{array}$ & $\begin{array}{l}30,736 \\
28,132\end{array}$ \\
\hline
\end{tabular}

TABLE III.-Effect of Tolbutamide on Disappearance of ${ }^{14} \mathrm{C}$-leucine from Rat-diaphragm Incubation Fluid

\begin{tabular}{|c|c|c|}
\hline $\begin{array}{l}\text { No. of } \\
\text { Experiments }\end{array}$ & $\begin{array}{l}\text { Incubation } \\
\text { Medium }\end{array}$ & $\begin{array}{l}\text { Mean Counts } / \min . / 5 \mu 1 . \\
\text { Medium after Incubation }\end{array}$ \\
\hline 6 & $\begin{array}{l}\text { Tolbutamide } 10^{-2} \\
\text { Control }\end{array}$ & $\left.\begin{array}{l}1,458 \\
1,108\end{array}\right\} P<0.01$ \\
\hline 6 & $\begin{array}{l}\text { Tolbutamide } 10^{-8} \\
\text { Control }\end{array}$ & $\begin{array}{l}1,076 \\
1,148\end{array}$ \\
\hline 5 & $\begin{array}{l}\text { Tolbutamide } 10^{-4} \\
\text { Control }\end{array}$ & $\begin{array}{l}426 \\
452\end{array}$ \\
\hline
\end{tabular}

was considerably more leucine remaining, nearly as much as in the control flasks incubated without diaphragms. Bornstein (1957) showed that carbutamide and tolbutamide in vitro inhibited a liver transaminase system involving alanine and oxoglutarate, and Manchester and Young (1958) demonstrated that incorporation of ${ }^{14} \mathrm{C}$-alanine into rat diaphragm was depressed by both carbutamide and tolbutamide. In both cases this effect was achieved with doses approximating to a concentration of $10^{-2}$, which is considerably more than that achieved therapeutically.

\section{Autoradiographic Studies}

The turnover of amino-acids in the acinar tissue of the pancreas is very rapid. However, there is also a good deal of labelled isotope taken up by the islets, and 14 days' exposure was adequate to observe any variations in radioactivity and to perform grain counts. On simple inspection no significant differences could be observed between the three groups of 
animals, either as a whole or at the various times of killing. Grain counts were therefore made, but again no significant differences were found.

\section{Discussion}

Since this study was begun Danowski et al. (1962) have shown that when leucine and tolbutamide are taken together the degree of hypoglycaemia is no greater than with tolbutamide alone, but the addition of leucine prolonged the duration of the hypoglycaemia. The leucine also increased tolbutamide-induced hypophosphataemia. Danowski et al. therefore suggested that sufficient extra insulin was released to produce further hypophosphataemia, but not further hypoglycaemia. Our studies have shown that tolbutamide can " sensitize" normal individuals to the hypoglycaemic effect of leucine, so it does appear that this is a general property of the sulphonylureas. Fajans et al. (1963) have clearly demonstrated that leucine-induced hypoglycaemia after chlorpropamide administration is associated with increased circulating insulin (immuno-assay) levels. They also found that, although oral leucine had no consistent effects on the blood sugar when administered intravenously, there was a small but fairly consistent fall in the blood sugar. This evidence would support Cochrane's (1960) hypothesis that the level of leucine in the plasma normally exerts some control over the rate of insulin release. If this hypothesis is correct, then the controlling effect must normally be small. However, in certain conditions-genetic predisposition, islet-cell tumours, and during sulphonylurea therapy-the normal effect of leucine is magnified.

The sensitizing effect of the sulphonylureas may be due to a variety of effects, but the two most likely hypotheses would seem to be $(a)$ that the drugs increase leucine uptake by the islets, or (b) that by stimulating insulin clearance from the islets they render the mechanisms of control of insulin production more sensitive to changes in plasma leucine (or glucose). The latter situation might apply with $\beta$-cell adenomata, where insulin synthesis and release are also increased by leucine. Our studies lend no support to the first hypothesis. Only in unphysiological amounts does tolbutamide affect in vitro leucine metabolism by muscle. And, although the autoradiographic method is only likely to reveal relatively gross differences in leucine uptake by the islets, our small study did not reveal any such difference. The method of studying the metabolism of isolated mammalian islets (Keen et al., 1963) may offer a more sensitive method of studying both hypotheses.

\section{Summary}

After the administration of tolbutamide normal individuals become sensitive to the hypoglycaemic effect of the amino-acid L-leucine. This effect could not, however, be demonstrated after the administration of another hypoglycaemic drug, phenformin. In vitro studies with the rat diaphragm failed to reveal any effect of tolbutamide upon leucine metabolism except in concentrations greater than those achieved therapeutically. No difference could be demonstrated in the uptake of injected ${ }^{14} \mathrm{C}$ leucine by the pancreatic islets between control rats and rats given a previous injection of tolbutamide or insulin, respectively.

The significance of these results is discussed.

We wish to acknowledge the help of Mr. K. Twinn, who prepared the autoradiographs. We are also grateful for the technical assistance of Miss Diana Bruce and Miss Brenda Sargeant.

\section{REFERENCES}

Bornstein, J. (1957). Nature (Lond.), 179, 534.

Butterfield, W. J. H., Arab, M. M. H., Buckle, A. L. J., Chlouverakis, C., Hanley, T., Mahler, R. F., and Whichelow, M. J. (1962). Diabetes,

11, Suppl. p. 43. W. Wright, P. H., and Woolf, L. I. (1960). Nature (Lond.), 188, 70.

Cochrane, W. A. (1960). 7. Dis. Child., 99, 476

Payne, W. W., Simpkiss, M. J., and Woolf, L. I. (1956). F. clin. Invest., 35, 411 .

Danowski, T. S., Bonessi, J. V., Balash, W. R., and Moses, C. (1962). Metabolism, 11, 556.

Fajans, S. S., Knopf, R. F., Floyd, J. C., jun., Power, L., and Conn, J. W. (1963). F. clin. Invest., 42, 216.

Power, L., Gwinup, G. W., Knopf, R. F., and Conn, J. W. (1960). 7. Lab. clin. Med., 56, 810 .

7. Lab. clin. Med., 56, 810. Chem., 120, 51.

Hoffman, W. S. (1937). F. biol. Chem., 120, 51. Demonstration to the Keen, H., Jarrett, R. J., and Sells, R. (1963). Dem

Manchester, K. L., and Young, F. G. (1958). Biochem. F., 70, 297.

Schwartz, T. B., Flanagan, G. C., Stuppy, G. W., and Tarum, D. W. (1959). ₹. Lab. clin. Med., 54, 944

Weisenfeld, S., and Goldner, M. G. (1961). Amer. f. Med., 31, 659.

Yalow, R. S., and Berson, S. A. (1960). F. clin. Invest., 39, 1157.

\title{
Acetohexamide in Treatment of Diabetes Mellitus
}

\author{
D. A. D. MONTGOMERY,* M.D., M.R.C.P. ; G. K. RASTOGI, † M.B., B.S., M.R.C.P., M.R.C.P.ED. \\ J. A. WEAVER, $\ddagger$ M.D., M.R.C.P.
}

Brit. med. F., 1964, 1, 868-871

The sulphonylureas tolbutamide and chlorpropamide have established their place as safe and effective drugs in the oral therapy of selected patients with stable diabetes mellitus. Nevertheless, the search for new hypoglycaemic drugs continues, and it is essential to subject each compound to critical study before it receives widespread clinical acceptance. Recently a new oral hypoglycaemic drug, acetohexamide ( $N$-p-acetylbenzenesulphonyl- $N$-cyclohexylurea), has become available and pre-

\footnotetext{
* Physician-in-Charge, Sir George E. Clark Metabolic Clinic, Royal Victoria Hospital, Belfast.

† Registrar, Sir George E. Clark Metabolic Clinic, Royal Victoria Hospitai, Belfast. Present address: Department of Endocrinology, AllIndia Institute of Medical Sciences, New Delhi.

‡ Physician, Sir George E. Clark Metabolic Clinic, Royal Victoria Hospital, Belfast.
}

liminary reports have been published (Balodimos et al., 1961 ; Weller et al., 1962 ; Maha et al., 1962 ; Owen, 1962 ; Boshell et al., 1962 ; Dobson, 1962). The purpose of this paper is to record our own experience with acetohexamide in treating 50 cases of diabetes mellitus.

\section{Methods}

The trial was designed to test the safety and effectiveness of the drug in patients attending the diabetes clinic at the Royal Victoria Hospital, Belfast. No attempt was made to compare its potency specifically with other hypoglycaemic drugs, although experience was gained in this respect. 